\title{
Assessment of Phosphorous Release from Bat Guano with Respect to Their use as Organic Fertilizers in Crop Production
}

\author{
Asha A. Hatibu ${ }^{*}$, Mawazo J. Shitindi ${ }^{2}$ and Ernest. M. M. Marwa ${ }^{3}$ \\ Researcher $^{1}$ and Professors ${ }^{2-3}$ \\ ${ }^{2-3}$ Department of Soil and Geological Sciences, College of Agriculture, Sokoine University of Agriculture, \\ P.O. Box 3008, Morogoro, Tanzania.
}

\begin{abstract}
Bat guano from Kisarawe cave A (BGK-A), Kisarawe cave B (BGK-B) and Sukumawera cave (BGS) in Tanzania were studied in a laboratory incubation experiment for 112 days to assess the phosphorus release patterns and establish the pick periods of $P$ mineralization. Total $P$ contents from BGK-A, BGK-B and BGS were 8.55, 7.03 and $3.45 \%$ respectively. Bat guano from each deposit mixed with soil at varying rates of $0,10,20,40$ and $80 \mathrm{mg} P 200 \mathrm{~g}^{-1}$ soil. The experiment was arranged as $3 \times 5$ factorial in randomized complete design (RCD) with three replications. Results showed a gradual increase of $P$ availability from 28 days to 84 days of incubation; followed by a gradual decrease up to the $112^{\text {th }}$ day of incubation. P release (availability) from the studied guano was in the order of $B G K-B<B G S<$ $B G K-A$. BGK-A indicated higher potential as an alternative $P$ source for agricultural application. $P$-source and application rate had a significant interaction effect $(P<0.05)$ on $P$ release at all incubation intervals when $P$ was applied at a rate of $80 \mathrm{mg} \mathrm{kg}^{-1}$ soil. The soil $\mathrm{pH}$ showed very strong negative correlation $(r>0.8)$ with $P$ released in the soil throughout incubation period. It was concluded that $P$ release from the three bat guano deposits is gradual and reaches the pick in almost three months after application. Thus, guano should be applied at least two months before planting for more effectiveness of $P$ release.
\end{abstract}

Keywords:Bat guano, Phosphorus release, Incubation, soil pH.

\subsection{INTRODUCTION}

Phosphorus (P) is an essential plant nutrient required for optimum crop growth [1]. It is the second most limiting plant nutrient after nitrogen $(\mathrm{N})$ in crop production [2]. Phosphorus plays vital roles in almost all plant processes including energy transfer, phosphate held as a part of the chemical structures of adenosine diphosphate (ADP) and adenosine triphosphate (ATP). It is the source of energy that drives large number of chemical reactions within the plant including phosphorylation process [3]. In photosynthesis, $\mathrm{P}$ utilizes light energy in the presence of chlorophyll to combine carbon dioxide and water into simple sugars, with the energy being captured in form of ATP which is available as an energy source for the many other reactions that occur within the plant. Through genetic transfer, $\mathrm{P}$ is a vital component of the substances that are building blocks of genes and chromosomes which involve in carrying genetic code from one generation to the next [4]. Also P involves in transportation of nutrients through the plant cells, movement of nutrients within the plant through cell membranes depends largely on energy whereby P in form of ATP compounds provide that energy [4]. In cereal crops such as rice, $\mathrm{P}$ increases panicle numbers, seed-setting rate and grain weight [5,6]. Moreover, it stimulates tillering, and often hastens maturity [7, 8]. It improves plant health and reduces the incidence and severity of many fungal diseases such as powdery mildew $[3,9,10]$.

Most of the tropical soils including Tanzanian soils are low in plant available phosphorus (P) [11]. The low level of plant available $\mathrm{P}$ in the tropical soils is due to either low levels of $\mathrm{P}$ in soil parent materials, highly weathered soils with high $\mathrm{P}$ fixing capacities or inadequate amounts of applied $\mathrm{P}$ fertilizer to replenish $\mathrm{P}$ losses through crop removal and other pathways [12]. Furthermore, industrial fertilizers are too limited in access and expensive for most 
smallholder farmers. This justifies the need for exploiting new and affordable fertilizers such as bat guano which could improve soil fertility and crop production while minimizing environmental pollution risks associated with misuse of chemical fertilizers. Guano deposits are found in a number of places in Tanzania and are continuously being deposited by bats and thus, they are renewable. Most research works have been conducted and reported about phosphorous and other nutrients release patterns of different manures other than bat guano [13-17]. In Tanzania, little information is known on the nutrients release patterns of guano when used as soil amendment and source of plant nutrients. Furthermore, the recommended rates of guano found in Tanzania for agriculture are not yet known. The objective of this study was to assess the phosphorous release from bat guano with respect to their use as organic fertilizers in crop production.

\subsection{MATERIALS AND METHODS}

\subsection{Geological settings of guano deposits}

\subsubsection{Kisarawe guano deposits}

Kisarawe guano deposits are found in Kisarawe district, $25 \mathrm{~km}$ west of Dar-es-salaam City (Fig.1). The site is located at $38^{\circ} 78^{\prime} \mathrm{E} / 7^{\circ} 20^{\prime} \mathrm{S}$. Formally the caves were used for mining kaolinite mineral in nineteen fifties to early nineteen seventies when they were abandoned and nowadays the caves are hosting bat colonies. The parent material of the caves is kaolinitic sandstone. The sandstone hosting bat guano is surrounded to the north and western side by clay bound gravels and to the eastern side by superficial white buff sands (Fig.1).

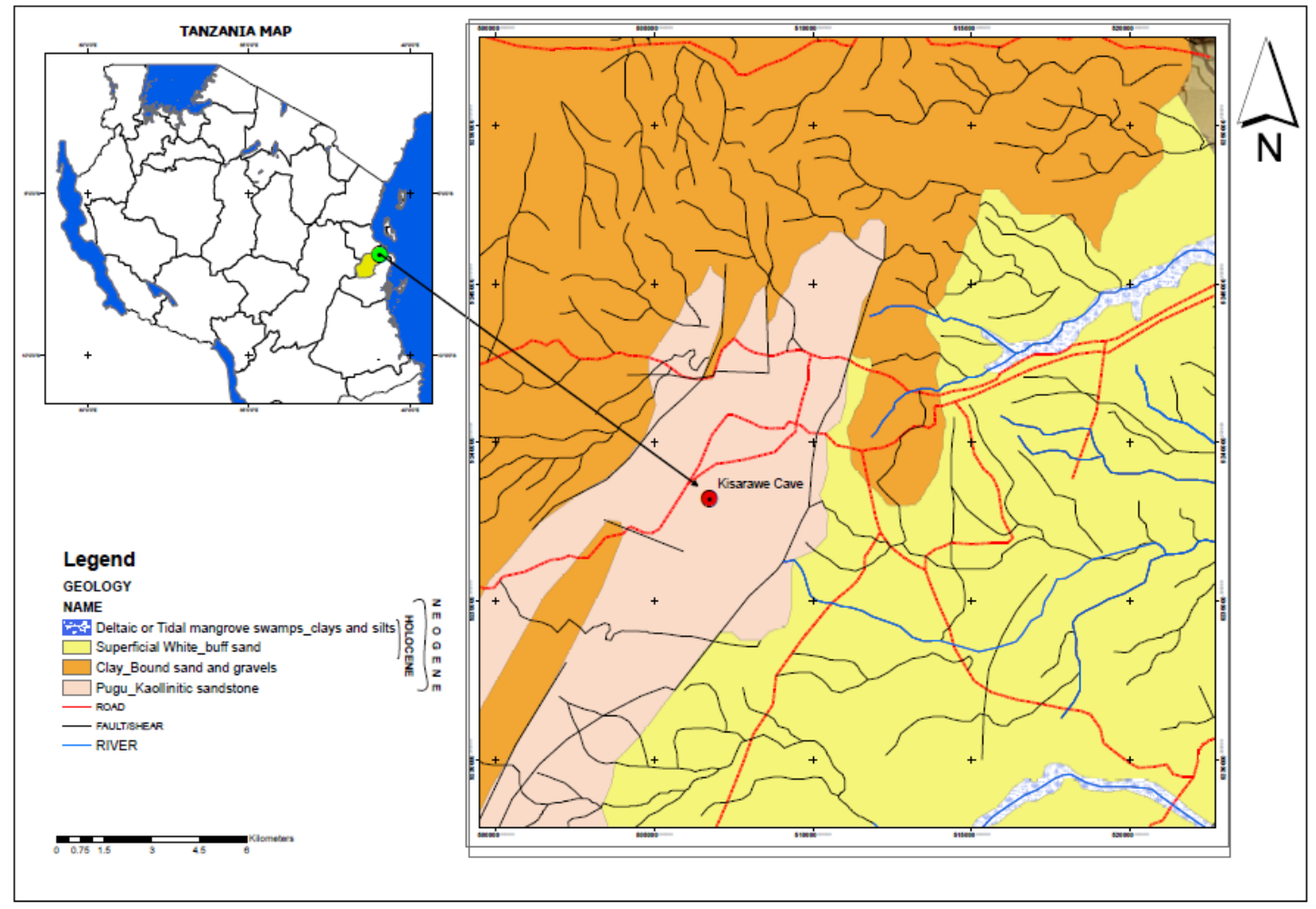

Figure 1: Geological setting of Kisarawe guano deposits

\subsubsection{Sukumawera guano deposit}

Sukumawera guano deposit is found at Maji moto sub village, near Songwe river, in Mbozi district. The site is located at $33^{\circ} 22^{\prime} \mathrm{E} / 8^{\circ} 89^{\prime} \mathrm{S}$. The cave is made of travertine (Carbonate rock) within the parent rock which is mainly dominated by Precambrian garnet biotite gneiss (Fig. 2). 


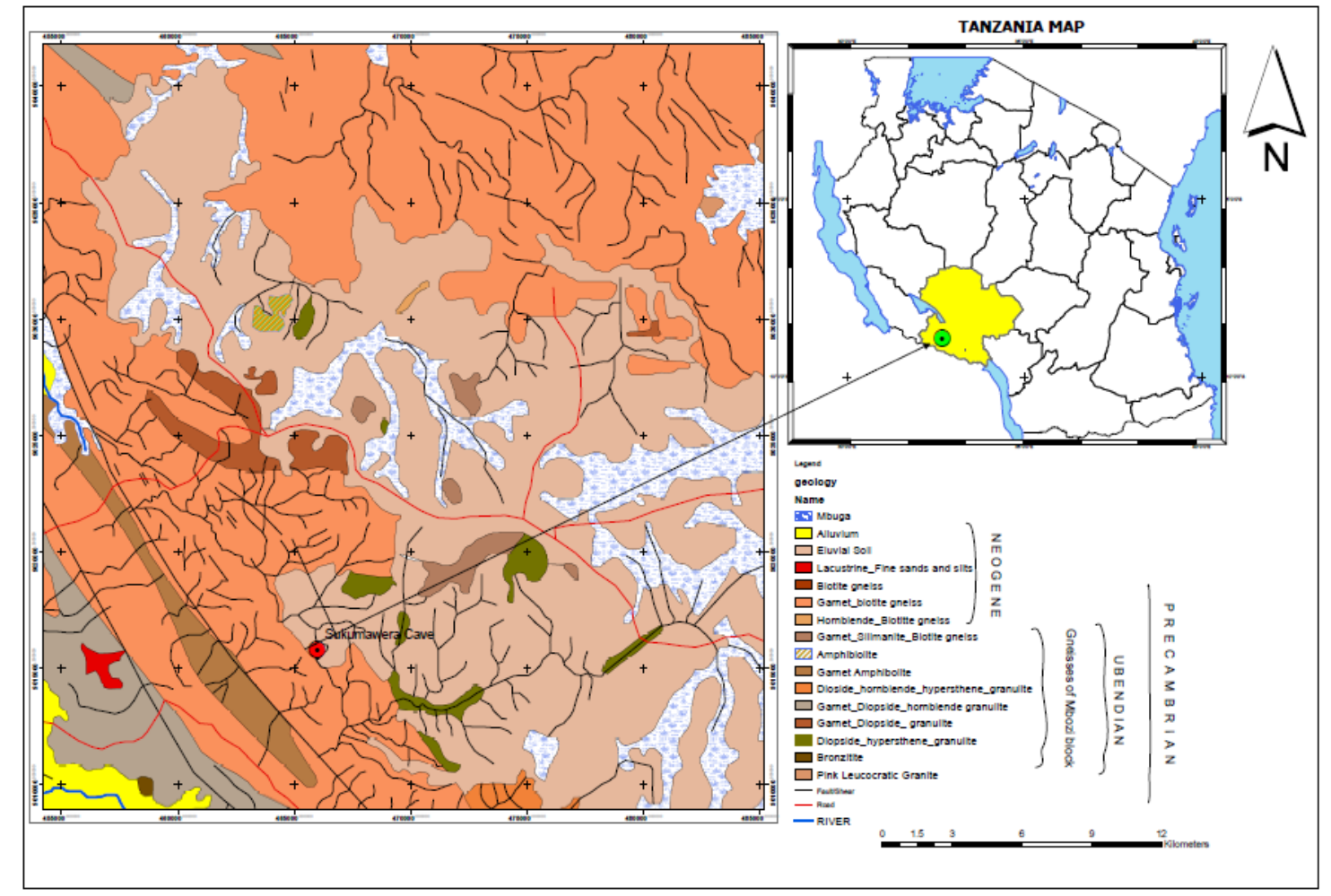

Fig.2. Geological setting of Sukumawera guano deposit

\subsection{Sampling and analysis of bat guano}

Three composite samples of guano were randomly collected from Kisarawe caves (A and B) and Sukumawera guano deposits. The samples were air-dried in a glasshouse, ground and sieved to pass through a $0.5 \mathrm{~mm}$ sieve, labeled and packed in bags and transported for determination of all total elemental composition at the Geological Survey of Tanzania (GST) laboratory by using X-ray Fluorescence (XRF01) pressed powder without binder. The analysis was done by using Maniple Analytical Software. While sub samples sieved through a $2 \mathrm{~mm}$ sieve and transported to the Soil and Geological Sciences laboratory at Sokoine University of Agriculture (SUA), in Morogoro Tanzania for determination of physical properties including moisture content (MC) and loss on ignition (LOI). Chemical properties determined were $\mathrm{pH}$, Electrical conductivity (EC), organic carbon (OC) and total $\mathrm{N}$ as described by $[18,19]$.

\subsection{Soil sampling and analysis}

A bulk soil sample was collected at 0-20 cm depth from the Soil and Geological Sciences experimental field, using the random sampling method in two diagonals. The soil was air dried, crushed and sieved through a $2 \mathrm{~mm}$ sieve for physical and chemical analysis. Particle size distribution was determined by the hydrometer method after dispersing soil sample in sodium hexametaphosphate solution [20]. Thereafter, the corresponding soil textural class was determined by using the USDA textural class triangle [21]. The $\mathrm{pH}$ of the soil was determined using a glass electrode pH meter in 1:2.5 (soil: water suspension) [22]. Electrical conductivity was measured in 1:2.5 (soil: water) by using conductivity meter [22]. Organic carbon was determined by Walkley and Black method using wet oxidation by potassium dichromate [23]. Total $\mathrm{N}$ was determined by the micro-Kjeldahl digestion procedure followed by distillation [18]. Available $\mathrm{P}$ was extracted following the procedure described by [24] and determined by ascorbic acid-colorimetric method using a Spectrophotometer [25]. Cation exchange capacity (CEC) was determined by using neutral ammonium-acetate saturation method $\left(\mathrm{NH}_{4} \mathrm{OAc}, \mathrm{pH}\right.$ 7) followed by Kjeldahl distillation method. Exchangeable $\mathrm{K}, \mathrm{Ca}, \mathrm{Mg}$ and $\mathrm{Na}$ were determined from the ammonium-acetate filtrates by Atomic Absorption Spectrophotometer [20].

\subsection{Experimental design}

The experiment was designed as a $3 \times 5$ factorial experiment laid down in a Completely Randomized Design (CRD) replicated three times. It consisted of two factors which were three P-sources from Kisarawe A, Kisarawe B and Sukumawera deposits at five different levels of application (Table 1). Bat guano was mixed thoroughly with soil, and 
the mixture was incubated in plastic containers covered with aluminum foil at the top to avoid contamination and covered with cotton wool at the bottom to avoid leaching. It was placed on the laboratory bench at $25^{ \pm} 1^{\circ} \mathrm{C}$ for 112 days. Incubation moisture was maintained around 50\% of field capacity by adding a predetermined amount of distilled water.

Table 1: $P$ rates used in an incubation experiment

\begin{tabular}{cccc}
\hline $\begin{array}{c}\text { P rate } \\
\left(\mathbf{m g P ~ k g}^{-\mathbf{1}}\right)\end{array}$ & \multicolumn{2}{c}{ Level of P applied from each source $\left(\mathbf{m g ~ P ~ 2 0 0 ~ \text { soil } ^ { - 1 } )}\right.$} \\
\cline { 2 - 4 } & BGK-A & BGK-B & BGS \\
\hline $\mathrm{P}_{0}$ & 0 & 0 & 0 \\
$\mathrm{P}_{10}$ & 0.023 & 0.028 & 0.06 \\
$\mathrm{P}_{20}$ & 0.046 & 0.056 & 0.12 \\
$\mathrm{P}_{40}$ & 0.092 & 0.112 & 0.24 \\
$\mathrm{P}_{80}$ & 0.184 & 0.224 & 0.48 \\
\hline
\end{tabular}

\subsection{Data collection}

After every 28 days, $5 \mathrm{~g}$ sub-sample of the incubated mixture was collected by using sterilized spatula cleaned using a cotton wool between sampling events. The samples were analyzed for $\mathrm{pH}$ in a 1:2.5 (soil: water) suspension [22] and $\mathrm{P}$ was extracted by the Olsen extraction method [24], followed by quantification of extractable P using ascorbic acid colorimetric method [25].

\subsection{Statistical analysis}

Analysis of variance was performed on extractable P determined at different intervals of incubation using GenStat Discovery $15^{\text {th }}$ edition Software. Treatment means were separated using Duncan New Multiple Range Test at the 5\% of probability level.

\subsection{RESULTS AND DISCUSSION}

\subsection{Physico-chemical properties of the soil used in the incubation experiment}

The physico-chemical properties of the soil used in the incubation study are as presented in Table 2. According to [26], the soil was slightly alkaline with $\mathrm{pH}$ of 7.2. Most plant nutrients are optimally available for plants between 6.5 to $7.5 \mathrm{pH}$ [27]. [26] revealed that when the $\mathrm{pH}$ is low, $\mathrm{P}$ can be fixed by $\mathrm{Al}, \mathrm{Fe}$ and $\mathrm{Mn}$ and at higher $\mathrm{pH}$ values above 7.5 $\mathrm{P}$ is precipitated by calcium and become insoluble. The $\mathrm{pH}$ of experimental soil was therefore within a range that guaranteed availability of $\mathrm{P}$ released from guano.

The electrical conductivity (EC) of the soil was $561 \mathrm{mS} / \mathrm{cm}$. According to [28] the level of EC is categorized as normal. [29] reported that under anaerobic condition EC has a tendency of showing positive correlation with phosphorus concentrations. The texture of the soil was sand clay. Sandy clay soils are likely to influence the availability of $P$ which is mineralized after amend the soil with bat guano. [30] and [31] reported that soil texture affects the availability of $\mathrm{P}$ by influencing soil organic matter (SOM) accumulation through mineralization and immobilization of SOM by microbial activity. The organic carbon (OC) of the soil was rated as very high while total $\mathrm{N}$ was medium [26]. Olsen extractable $\mathrm{P}$ was relatively higher than the critical value for deficiency $\left(4.25 \mathrm{mg} \mathrm{P} \mathrm{kg}^{-1}\right)$ as reported by [32]. Moreover, [28] reported that Olsen extractable $\mathrm{P}$ higher than $6 \mathrm{mg} \mathrm{P} \mathrm{kg}^{-1}$ is regarded as medium.

Table 2: Chemical and physical properties of soil collected for incubation experiment

\begin{tabular}{cccc}
\hline Parameter & SI-unit & Value & Rating [28][26] \\
\hline $\mathrm{pH}\left(\mathrm{H}_{2} \mathrm{O}\right)$ & & 7.2 & Normal \\
$\mathrm{EC}$ & $\mathrm{mS} / \mathrm{cm}$ & 561 & Normal \\
OC & $\%$ & 11.05 & Very High \\
Total N & $\%$ & 0.48 & Medium \\
Olsen Extractabl P & $\mathrm{mg} / \mathrm{Kg}$ & 6.59 & Medium \\
Exch.Calcium & $\mathrm{Cmol}(+) \mathrm{Kg}^{-1}$ & 7.97 & Medium \\
Exch.Sodium & $\mathrm{cmol}(+) \mathrm{Kg}^{-1}$ & 3.98 & Very High \\
Exch. Magnesium & $\mathrm{cmol}(+) \mathrm{Kg}^{-1}$ & 5.12 & High \\
Exch. Potassium & $\mathrm{cmol}(+) \mathrm{Kg}^{-1}$ & 6.07 & Very High \\
CEC & $\mathrm{cmol}(+) \mathrm{Kg}^{-1}$ & 20.2 & Medium \\
\hline
\end{tabular}


International Journal of Advances in Scientific Research and Engineering (ijasre), Vol 6 (11), November -2020

\begin{tabular}{cccc}
\hline Particle size & $\%$ & 49.3 & \\
Sand & $\%$ & 41.1 & \\
Clay & $\%$ & 9.6 & Sand Clay \\
Silt & & & \\
Textural class & & & \\
\hline
\end{tabular}

\subsection{Total elemental compositions of Kisarawe and Sukumawera bat guano}

Table 3 shows the result of the total elemental composition of Kisarawe and Sukumawera bat guano used in this study. The results showed relatively higher total P (8.55\%) from BGK-A than BGK-B (7.03\%) and BGS (3.45\%). [33] reported total $\mathrm{P}$ content of Kisarawe bat guano in the range of $7-15 \%$ P. Higher P concentration in Kisarawe caves A and $\mathrm{B}$ might be due to high accumulation of daily fresh bat faeces [35]. Total P content determined in Sukumawera guano (3.45\%) was lower and different from total P content of 20 - 41\% previously reported by [33] using guano from the same deposit. Such differences might have been caused by decomposition of bat guano followed by gradual leaching of nutrients including $\mathrm{P}[35,36,37]$.

Table 3: Total elemental compositions of Kisarawe and Sukumawera bat guano

\begin{tabular}{llll}
\hline Element & \multicolumn{3}{c}{ Guano type and total composition (\%) } \\
\cline { 2 - 4 } & BGK-A & BGK-B & BGS \\
\hline $\mathrm{Al}$ & 5.82 & 11.11 & Trace \\
$\mathrm{Si}$ & 4.21 & 10.11 & 2.34 \\
$\mathrm{P}$ & 8.55 & 7.03 & 3.45 \\
$\mathrm{~S}$ & 7.49 & 4.25 & 2.87 \\
$\mathrm{~K}$ & 11.04 & 6.34 & 3.98 \\
$\mathrm{Ca}$ & 6.70 & 4.92 & 45.67 \\
$\mathrm{Ti}$ & 1.98 & 0.35 \\
$\mathrm{Mn}$ & 0.36 & 1.40 & 0.31 \\
$\mathrm{Fe}$ & 4.41 & 4.70 \\
$\mathrm{Zn}$ & 0.86 & 0.38 \\
$\mathrm{Sr}$ & 2.71 & 0.10 & 1.23 \\
$\mathrm{Pd}$ & 1.25 & 0.14 & 0.05 \\
$\mathrm{Cu}$ & 0.09 & 0.05 & 0.03 \\
$\mathrm{~Pb}$ & 0.11 & 0.01 & $<0.01$ \\
$\mathrm{Zr}$ & 0.04 & 0.03 & 0.01 \\
$\mathrm{Sr}$ & $<0.01$ & 0.01 & 0.21 \\
$\mathrm{Rh}$ & 0.01 & 0.07 & 0.03 \\
\hline
\end{tabular}

Potassium (K) is among the major nutrient elements required by plants. Total $\mathrm{K}$ in guano from Kisarawe cave A was found to be higher (11.4\%) compared to total K obtained from Kisarawe cave B (6.3\%) and Sukumawera cave (4.0\%). The differences could be attributed to variations in the nature and composition of parent material around the caves and that of food consumed by bats. Generally, total P and K contents of guano from Kisarawe caves A and B were above $5 \%$ recommended by FAO as a minimum for any material to qualify as a fertilizer the rate at which the nutrients are released from the guano would still influence its potential for use as $\mathrm{P}$ source in crop production. Other nutrient elements contained in guano include calcium which was higher in guano from Sukumawera deposit (45\%) than the other two deposits mainly because of high Ca contents in parent material of Sukumawera cave. The parent material of Sukumawera cave is mainly composed of gneiss and travertine rocks which contain amphibole, pyroxene and calcite minerals [38].

Total Manganese in the three bat guano was low, similar to the findings reported by [33]. Furthermore, total S in the three bat guano was also low. The data reported by [33] was contrary to these findings. [33] reported higher total $\mathrm{S}$ in Kisarawe caves than values observed in this study probably due to variation of total $\mathrm{S}$ contents between sampling points and time intervals as influenced by various factors. Apart from $\mathrm{Si}$ and $\mathrm{Al}$ which were relatively higher in 
Kisarawe cave $\mathrm{A}$ and $\mathrm{B}$ deposits, heavy metals $(\mathrm{Pb}, \mathrm{Pd}, \mathrm{Rh}, \mathrm{Ti}, \mathrm{Sr}$, and $\mathrm{Zr}$ ) were found in relatively smaller amounts in the three deposits suggesting that application of guano as organic fertilizer is safe and can't be associated with high risks of Potential toxic elements (PTEs) accumulation in the soil environment.

\subsection{Physico-chemical properties of guano used in the experiment}

Table 4 shows some physico-chemical properties of bat guano used in this study. The physical chemical properties assessed include $\mathrm{pH}$, electrical conductivity (EC), moisture content (MC), loss on ignition (LOI), organic carbon (OC) and Total nitrogen. The $\mathrm{pH}$ of Kisarawe bat guano from caves A and B (BGK-A and BGK-B) was quite different. Guano from cave A was slightly acidic with a pH of 6.1, while $\mathrm{pH}$ of guano from cave B (4.3) was extremely acid [26, 28]. Extremely low $\mathrm{pH}$ of BGK-B coupled with high levels of $\mathrm{Al}$ and $\mathrm{Si}$ are likely to restrict $\mathrm{P}$ release for plant uptake from this guano because solubility (activity) of both $\mathrm{Al}$ and $\mathrm{Si}$ which have high affinity for $\mathrm{P}$ increases with decreasing $\mathrm{pH}$ hence increasing $\mathrm{P}$ fixing sites in the soil. The $\mathrm{pH}$ of guano from caves $\mathrm{A}$ and $\mathrm{B}$ were different although these guanos are from the same geographical location but found in different caves. Their differences are possibly caused by high amount of organic carbon $27.95 \%$ in cave B compared to $21.45 \%$ in cave A. [39] reported that soil which has high organic matter which has a relation and estimated by the determination of soil organic carbon (SOC) has greater capacity of holding hydrogen ions; therefore it has high ability of reserving acidity. Moreover, [27] explained that cation and anion exchange capacity are largely determined by the charges of the SOM which are influenced by $\mathrm{pH}$. High amounts of organic matter typically have higher cation exchange capacity (CEC), thus able to bind more cations such as calcium or potassium, aluminum and hydrogen ions which have a tendency of lowering $\mathrm{pH}$. In addition $\mathrm{pH}$ differences may be contributed by the nature of rocks and rock forming minerals in and around the caves.

Table 1: The physico-chemical properties of Kisarawe and Sukumawera bat guano

\begin{tabular}{llll}
\hline Parameter & \multicolumn{3}{c}{ Guano type } \\
\cline { 2 - 4 } & BGK-A & BGK-B & BGS \\
\hline $\mathrm{pH}($ water $)$ & 6.1 & 4.3 & 6.3 \\
$\mathrm{ECe}\left(\mathrm{mS} \mathrm{cm} \mathrm{cm}^{-1}\right)$ & 17.77 & 3.28 & 28.53 \\
$\mathrm{OC}(\%)$ & 21.45 & 27.95 & 35.10 \\
$\mathrm{MC}(\%)$ & 14.55 & 19.71 & 21.69 \\
LOI $(\%)$ & 26.23 & 7.7 & 15.88 \\
Total N $(\%)$ & 4.08 & 5.51 & 5.57 \\
\hline
\end{tabular}

\subsection{Effect of incubation time on $P$ release}

The amounts of P released and determined as Olsen extractable P during incubation for 112 days are depicted in Fig. 3. $\mathrm{P}$ releases were generally in three regions; the first region was fast release of $\mathrm{P}$ and was immediately after day 0 to day 56 of incubation. The second region was slow release which was from 56 to day 84 days of incubation. The third region in which $\mathrm{P}$ release was decreasing started from day 84 to day 112. These results were in line with findings reported by [40] and [41]. Both studies reported increase in available $\mathrm{P}$ followed by decrease in the release of $\mathrm{P}$. Studies of [42] and [43] showed that as the time of incubation increases the P availability in soil decreases for both organic and inorganic $\mathrm{P}$ sources due to rapid microbial immobilization of the added sources. The trend can also be due to fixation of released $\mathrm{P}$ by both soil and guano components such as $\mathrm{Al}, \mathrm{Fe}$ and $\mathrm{Si}$ with high affinity for P. Although BGK-B had higher total $\mathrm{P}$ than BGS, BGK-B released less amount of $\mathrm{P}$ at all sampling intervals further suggesting that elevated levels of $\mathrm{Al}$ and $\mathrm{Si}$ in $\mathrm{BGK}-\mathrm{B}$ restricted $\mathrm{P}$ release or fixed $\mathrm{P}$ after release from the guano making it less available for plant uptake. 
International Journal of Advances in Scientific Research and Engineering (ijasre), Vol 6 (11), November -2020

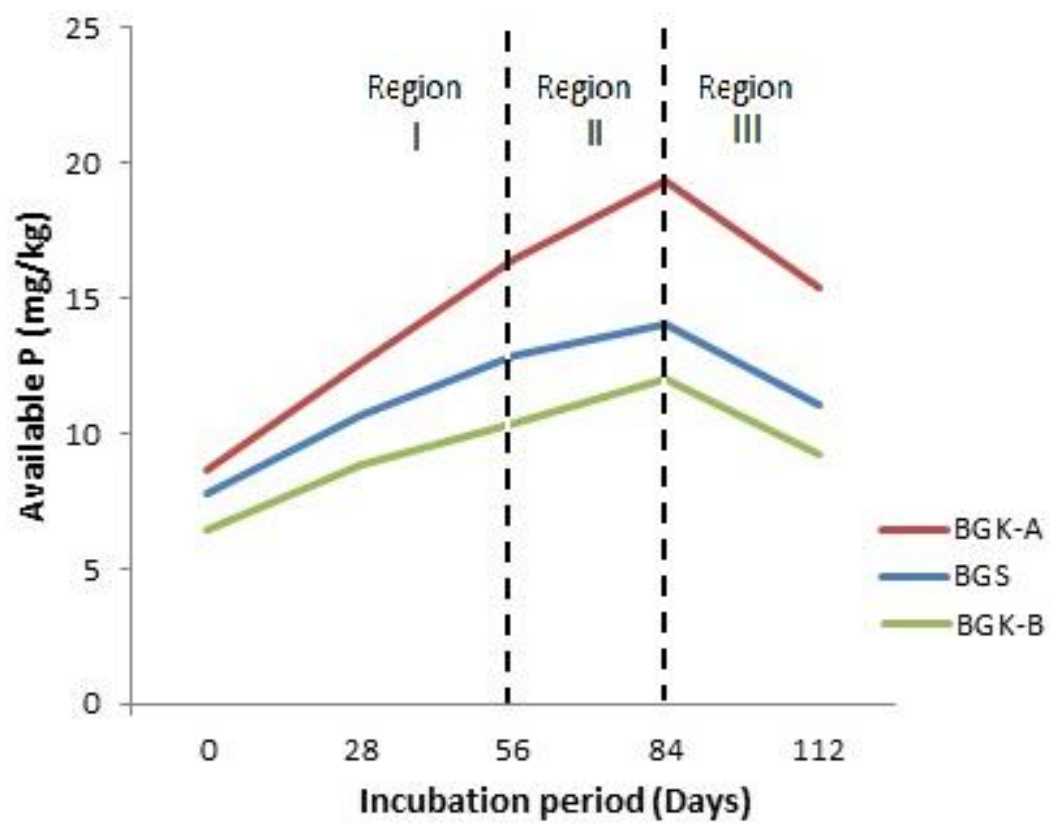

Figure 3.P release from different guano at varying incubation intervals.

\subsection{Effect of $P$ - rates and interaction between $P$-sources and rates on $P$ release}

The $\mathrm{P}$ release significantly increased with increasing application rates of all $\mathrm{P}$ - sources (Table 5). Application of guano at a rate of $80 \mathrm{mg} \mathrm{kg}^{-1}$ resulted into the highest level of $\mathrm{P}$ release from all $\mathrm{P}$ sources. These findings are similar to those of [41]. They reported that phosphate release increase significantly with increase in initial phosphorus levels and decreased with increasing incubation period. The $\mathrm{P}$ released was significantly $(\mathrm{P}<0.05)$ higher for BGK-A followed by BGS and BGK-B (Fig. 3).

Table 2: Effect of $P$-rates on $P$ release at varying incubation intervals

\begin{tabular}{llllll}
\hline P-rates $\left(\mathbf{m g ~ k g}^{-1}\right)$ & \multicolumn{5}{c}{ Days of incubation } \\
\cline { 2 - 6 } & $\mathbf{0}$ & $\mathbf{2 8}$ & $\mathbf{5 6}$ & $\mathbf{8 4}$ & $\mathbf{1 1 2}$ \\
\hline P0 & $5.02 \mathrm{a}$ & $4.98 \mathrm{a}$ & $5.21 \mathrm{a}$ & $5.6 \mathrm{a}$ & $5.45 \mathrm{a}$ \\
P10 & $6.99 \mathrm{~b}$ & $10.26 \mathrm{~b}$ & $13.43 \mathrm{~b}$ & $14.85 \mathrm{~b}$ & $11.17 \mathrm{~b}$ \\
P20 & $7.85 \mathrm{c}$ & $10.92 \mathrm{c}$ & $14.59 \mathrm{bc}$ & $16.58 \mathrm{c}$ & $12.94 \mathrm{c}$ \\
P40 & $8.77 \mathrm{~d}$ & $12.01 \mathrm{~d}$ & $15.40 \mathrm{c}$ & $18.55 \mathrm{~d}$ & $14.31 \mathrm{~d}$ \\
P80 & $9.40 \mathrm{e}$ & $14.16 \mathrm{e}$ & $17.55 \mathrm{~d}$ & $20.22 \mathrm{e}$ & $15.60 \mathrm{e}$ \\
Mean & 7.61 & 10.46 & 13.24 & 15.16 & 11.89 \\
CV \% & 4.8 & 4.5 & 11.4 & 4.2 & 5.7 \\
F-pro & $<0.001$ & $<0.001$ & $<0.001$ & $<0.001$ & $<0.001$
\end{tabular}

Means in the same column followed by the same letter(s) are not significantly different at 5\% level of significance according to Duncan New Multiple Range Test. Means in each column analyzed separately.

Furthermore, there was highly significant $(\mathrm{P}<0.05)$ interaction effect between $\mathrm{P}$-sources and rates on $\mathrm{P}$ released in soil following incubation (Table 6). The overall mean results showed significantly higher $\mathrm{P}$ release $(\mathrm{P}<0.05)$ from BGK-A and BGS at the rate of 40 and $80 \mathrm{mg} \mathrm{kg}^{-1}$ as compared to $\mathrm{P}$ released from equivalent rates of BGK-B. These differences were due to variations in their $\mathrm{pH}, \mathrm{Al}$ and probably $\mathrm{Si}$ contents. BGK-A and BGS were slightly acidic while that of BGK-B was strongly acidic with higher total Al and Si contents (Table 4). According to [44] fertilizers with lower $\mathrm{pH}$ prevent $\mathrm{P}$ availability in soil due to $\mathrm{P}$ fixation. 
International Journal of Advances in Scientific Research and Engineering (ijasre), Vol 6 (11), November -2020

Table 3: Interaction effect of $P$-sources and rates on $P$ released at varying incubation intervals

\begin{tabular}{|c|c|c|c|c|c|c|}
\hline \multirow{2}{*}{\multicolumn{2}{|c|}{$\begin{array}{c}\text { P-Source Rates } \\
\left(\mathrm{mg} \mathrm{kg}^{-1}\right)\end{array}$}} & \multicolumn{5}{|c|}{ Days of incubation } \\
\hline & & \multirow{2}{*}{$\frac{\text { 0 }}{5.28 \mathrm{ab}}$} & \multirow{2}{*}{$\frac{28}{5.18 \mathrm{a}}$} & \multirow{2}{*}{$\frac{56}{5.79 \mathrm{a}}$} & \multirow{2}{*}{$\frac{84}{5.50 \mathrm{ab}}$} & \multirow{2}{*}{$\frac{112}{5.19 \mathrm{a}}$} \\
\hline BGK-A & 0 & & & & & \\
\hline BGK-A & 10 & $8.82 \mathrm{f}$ & $13.68 \mathrm{f}$ & $17.93 \mathrm{e}$ & $20.47 \mathrm{~g}$ & $16.31 \mathrm{fg}$ \\
\hline BGK-A & 20 & $9.30 \mathrm{fg}$ & $14.14 \mathrm{f}$ & $18.81 \mathrm{e}$ & $22.02 \mathrm{~h}$ & $17.44 \mathrm{~g}$ \\
\hline BGK-A & 40 & $9.61 \mathrm{gh}$ & $14.48 \mathrm{f}$ & $19.13 \mathrm{e}$ & $23.69 \mathrm{i}$ & $18.66 \mathrm{~h}$ \\
\hline BGK-A & 80 & $10.09 \mathrm{~h}$ & $15.36 \mathrm{~g}$ & $20.54 \mathrm{e}$ & $25.41 \mathrm{j}$ & $19.28 \mathrm{~h}$ \\
\hline BGK-B & 0 & $4.65 \mathrm{a}$ & $4.76 \mathrm{a}$ & $4.74 \mathrm{a}$ & $6.23 \mathrm{~b}$ & $6.15 \mathrm{a}$ \\
\hline BGK-B & 10 & $5.59 \mathrm{~b}$ & $8.21 \mathrm{~b}$ & $10.69 \mathrm{~b}$ & $11.35 \mathrm{c}$ & $7.70 \mathrm{~b}$ \\
\hline BGK-B & 20 & $6.38 \mathrm{c}$ & $9.01 \mathrm{bc}$ & $11.18 \mathrm{bc}$ & $13.07 \mathrm{~d}$ & $9.59 \mathrm{c}$ \\
\hline BGK-B & 40 & $7.25 \mathrm{e}$ & $10.40 \mathrm{~d}$ & $12.18 \mathrm{bcd}$ & $12.73 \mathrm{~d}$ & $10.79 \mathrm{~d}$ \\
\hline BGK-B & 80 & $8.12 \mathrm{e}$ & $11.78 \mathrm{e}$ & $13.10 \mathrm{bcd}$ & $14.66 \mathrm{e}$ & $11.88 \mathrm{~d}$ \\
\hline BGS & 0 & $5.12 \mathrm{ab}$ & $5.01 \mathrm{a}$ & $5.11 \mathrm{a}$ & $5.07 \mathrm{a}$ & $5.02 \mathrm{a}$ \\
\hline BGS & 10 & $6.54 \mathrm{c}$ & $8.88 \mathrm{bc}$ & $11.66 \mathrm{bc}$ & $12.73 \mathrm{~d}$ & $9.50 \mathrm{c}$ \\
\hline BGS & 20 & $6.54 \mathrm{c}$ & $9.60 \mathrm{c}$ & $13.79 \mathrm{~cd}$ & $14.66 \mathrm{e}$ & $11.80 \mathrm{~d}$ \\
\hline BGS & 40 & $7.88 \mathrm{e}$ & 11.14de & $14.90 \mathrm{~d}$ & $17.33 \mathrm{f}$ & $13.47 \mathrm{e}$ \\
\hline BGS & 80 & $10.01 \mathrm{~h}$ & $15.32 \mathrm{~g}$ & $19.01 \mathrm{e}$ & $20.30 \mathrm{~g}$ & $15.65 \mathrm{f}$ \\
\hline \multicolumn{2}{|c|}{ Mean } & 7.61 & 10.46 & 13.24 & 15.16 & 11.89 \\
\hline \multicolumn{2}{|c|}{$\mathrm{CV} \%$} & 4.8 & 4.5 & 11.4 & 4.2 & 5.7 \\
\hline \multicolumn{2}{|c|}{ F-pro } & $<0.001$ & $<0.001$ & 0.003 & $<0.001$ & $<0.001$ \\
\hline
\end{tabular}

Means in the same column followed by the same letter(s) are not significantly different at $5 \%$ level of significance according to

Duncan New Multiple Range Test. Means in each column analyzed separately.

\subsection{Effect of $\mathrm{pH}$ on $\mathrm{P}$ release}

The $\mathrm{pH}$ of the soil was correlated with $\mathrm{P}$ release from 0 to 112 days of incubation. The results showed a very strong negative correlation between soil $\mathrm{pH}$ and $\mathrm{P}$ released $(\mathrm{r}>0.8)$ as shown in figures $4-6$. This implies that as the time goes on, the $\mathrm{P}$ release was decreasing in the meantime the soil $\mathrm{pH}$ was increased. As $\mathrm{P}$ is higher the $\mathrm{pH}$ become lower and vice versa. The results are in agreement with the findings of [45] who reported negative correlation between available $\mathrm{P}$ and $\mathrm{pH}$ values of soil. In BGK-A the correlation was highest in day $112(\mathrm{r}=-0.982)$ and lowest in day 56 $(\mathrm{r}=-0.928)$ (Fig. 4 e, c). In BGK-B the correlation was highest in day $0(\mathrm{r}=-0.985)$ and lowest during day $56(\mathrm{r}=-$ 0.884) (Fig. 5 a, c). Similarly in BGS, result showed that correlation was highest in day $0(r=-0.998)$ and lowest in day $56(\mathrm{r}=-0.943)$ (Fig. $6 \mathrm{a}, \mathrm{c})$. These results showed that as the soil $\mathrm{pH}$ decrease in a range of 5.5-6.5 the $\mathrm{P}$ availability increases. Below the soil $\mathrm{pH}$ of 5.5, the release of $\mathrm{P}$ in soil become difficult because $\mathrm{P}$ reacts with iron and aluminum to form insoluble compounds that makes it unavailable to plants. These results are in line with observations made by [46]. The results also agreed with findings attained by [47]. [47] reported that phosphorus availability is higher in moderately acidic soil. Moreover, in this study, the $\mathrm{pH}$ decreased as the rate of guano increases probably because of acidic nature of the guano. This finding is supported by [48] who reported the addition of organic resources to soils may result in $\mathrm{pH}$ changes due to microbial activity during residue breakdown. Also, [45] reported that application of phosphorus fertilizers can cause the decrease of the $\mathrm{pH}$ values in soils. 
International Journal of Advances in Scientific Research and Engineering (ijasre), Vol 6 (11), November -2020

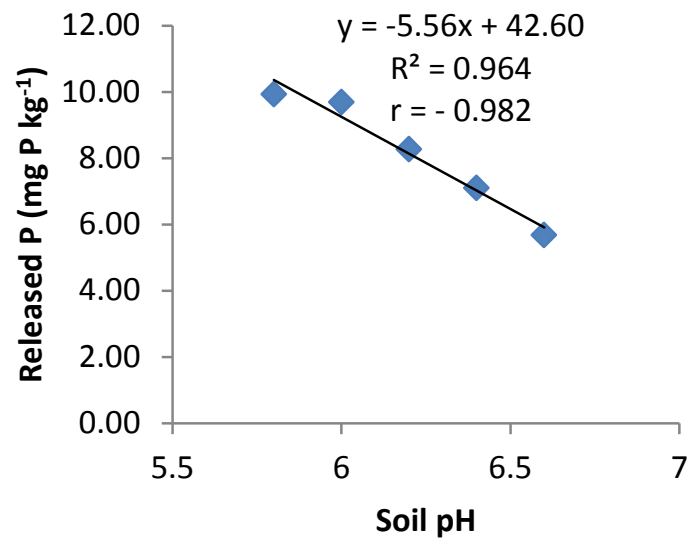

(a)

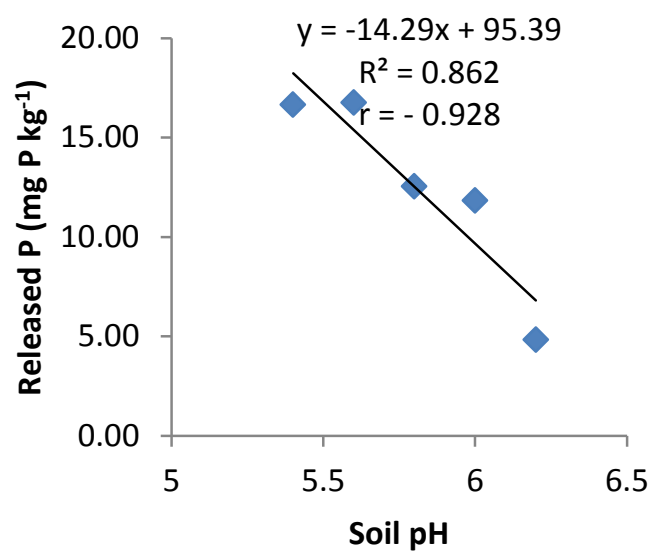

(c)

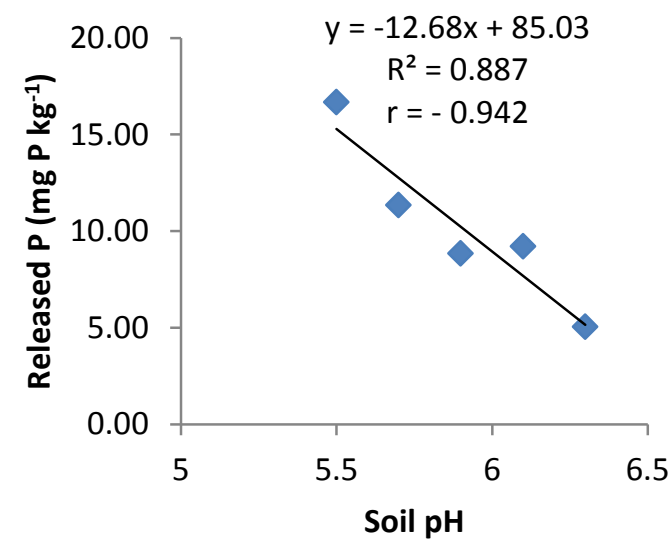

(b)

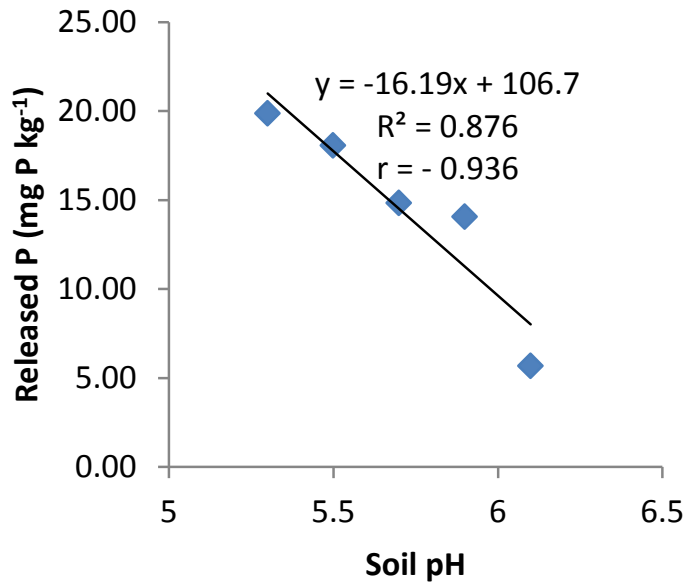

(d)

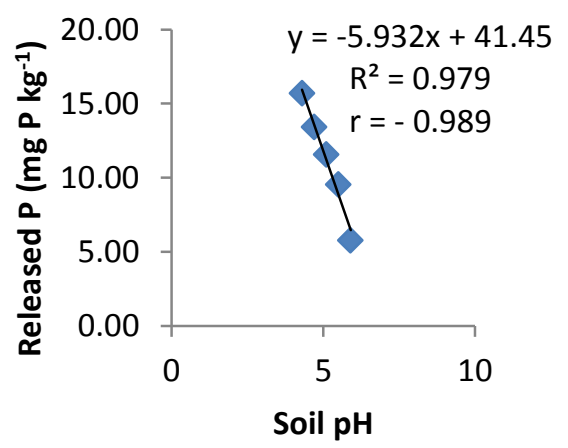

(e)

Figure 4: Correlation of $\mathrm{P}$ released from BGK-A at 0, 10, 20, 40 and $80 \mathrm{mg} \mathrm{P} \mathrm{kg}^{-1}$ with pH at (a) day 0, (b) day 28, (c) day 56, (d) day 84 and (e) day112 of incubation 
International Journal of Advances in Scientific Research and Engineering (ijasre), Vol 6 (11), November -2020

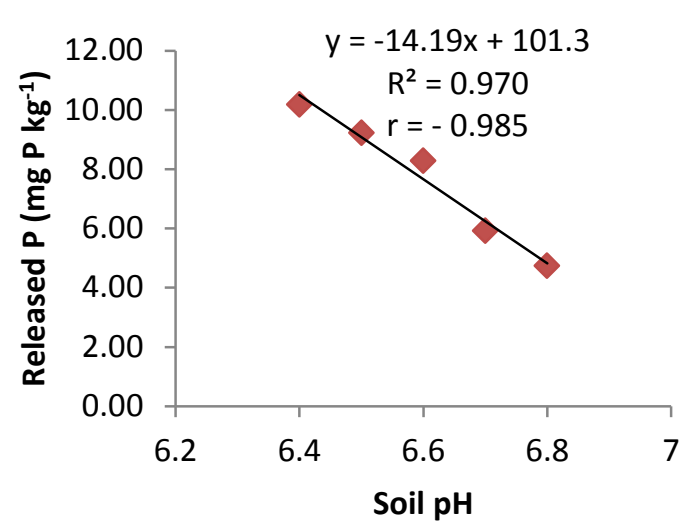

(a)

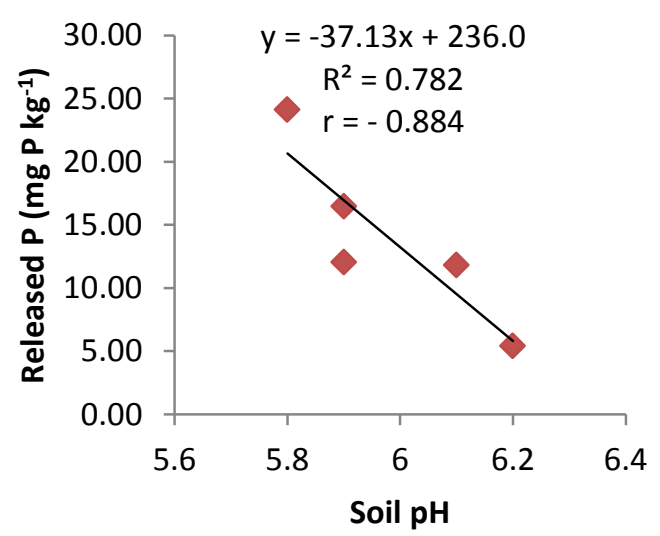

(c)

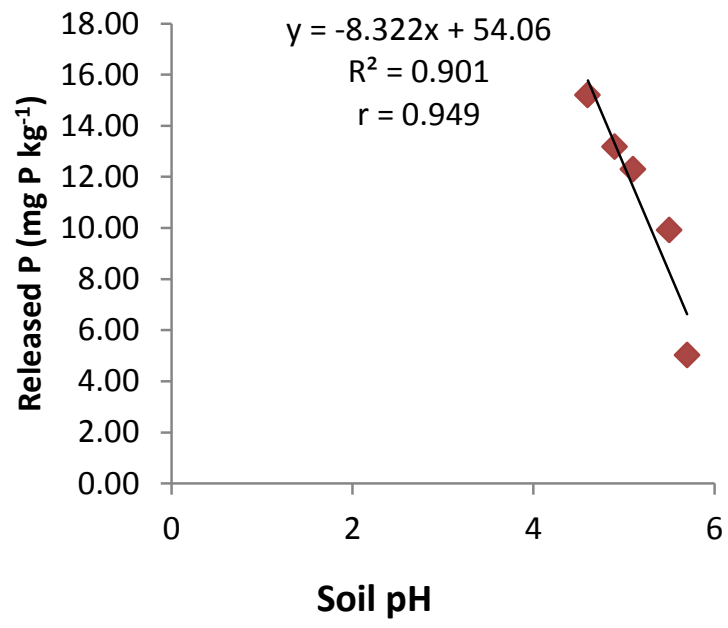

(e)

Figure 5: Correlation of P released from BGK-B at 0, 10, 20, 40 and $80 \mathrm{mg} \mathrm{Pg}^{-1}$ with pH at (a) day 0, (b) day 28, (c) day 56, (d) day 84 and (e) day112 of incubation

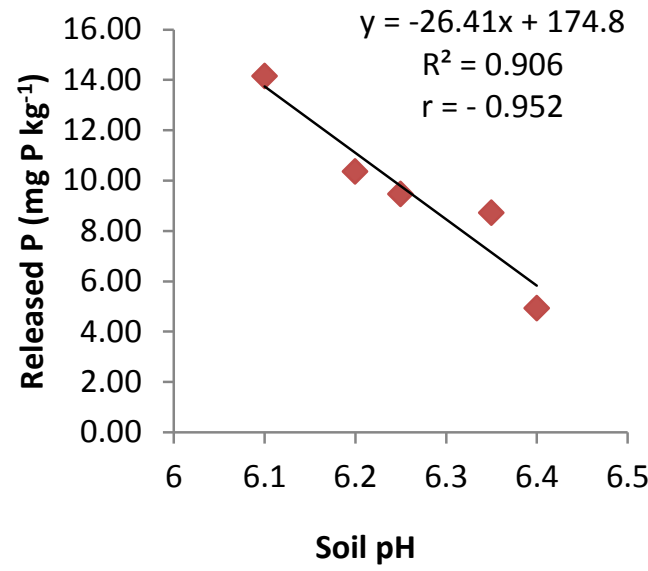

(b)

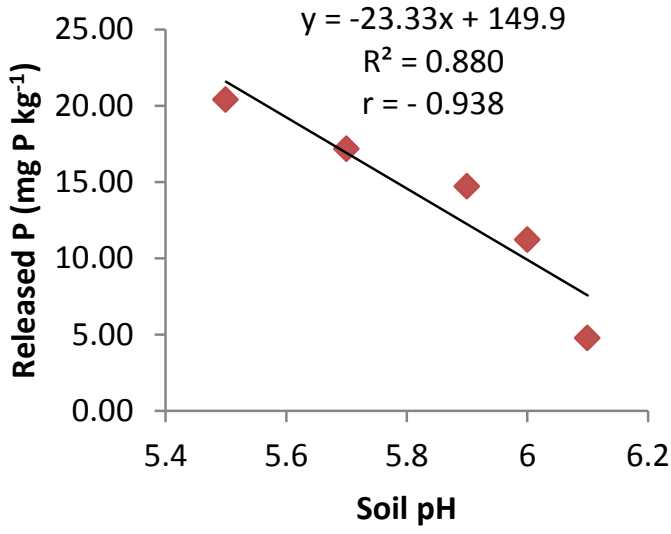

(d) 
International Journal of Advances in Scientific Research and Engineering (ijasre), Vol 6 (11), November -2020

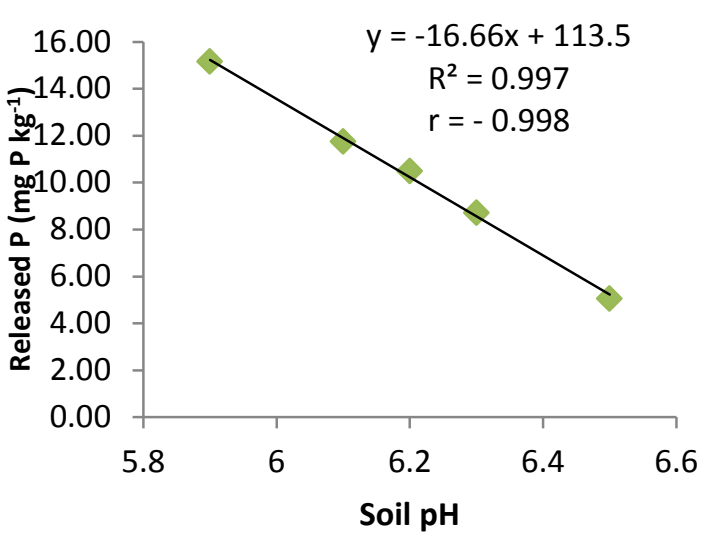

(a)

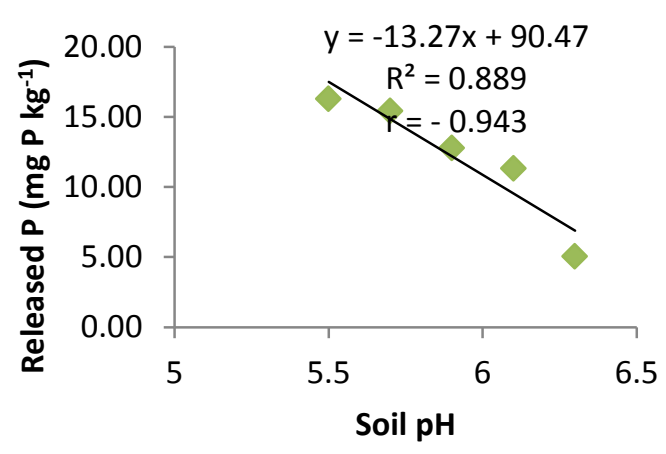

(c)

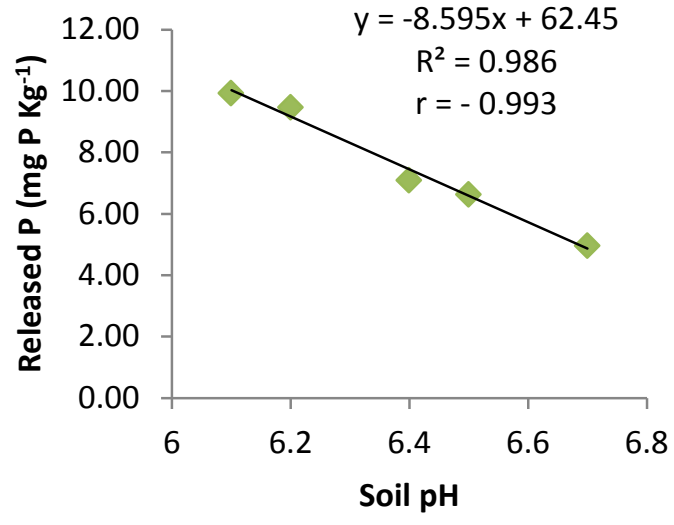

(b)

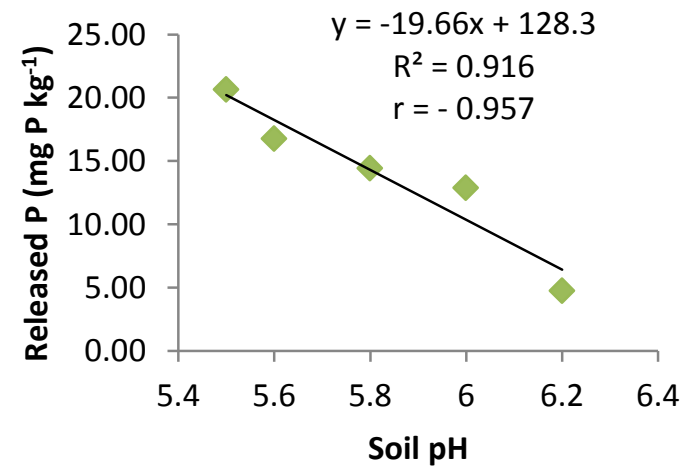

(d)

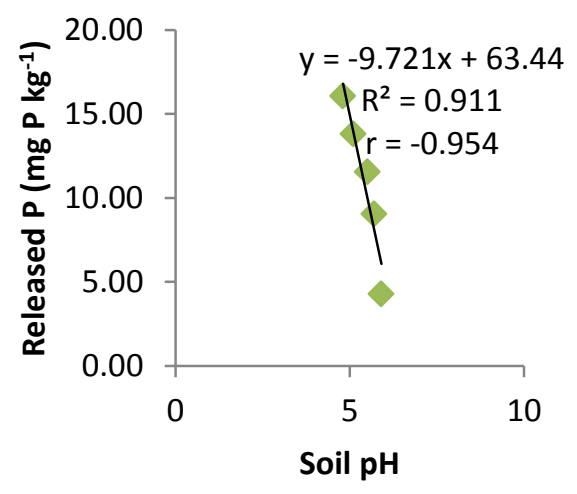

(e)

Figure6: Correlation of P released from BGS at 0,10, 20, 40 and $80 \mathrm{mg} \mathrm{P} \mathrm{kg}^{-1}$ with $\mathrm{pH}$ at (a) day 0 , (b) day 28, (c) day 56, (d) day 84 and (e) day112 of incubation

\section{CONCLUSIONS AND RECOMMENDATIONS}

Guano from Kisarawe cave A (BGK-A) decomposed more rapidly in the soil and released more available $\mathrm{P}$ than guano from Kisarawe cave B (BGK-B) and that from Sukumawera (BGS). In all three P sources, application of guano at a rate of $80 \mathrm{mg} \mathrm{P} \mathrm{kg}^{-1}$ of soil resulted into the highest level of $\mathrm{P}$ release at 84 days of incubation but increasing the duration of incubation beyond 84 days resulted into a gradual decrease in P release to 112 days. Furthermore the study found a negative correlation between $\mathrm{P}$ release from guano and $\mathrm{pH}$ of soil. These results implied that $\mathrm{P}$ released from guano could be much more available for plant uptake when applied three months earlier before planting especially for annual crops. However, field trials are recommended to validate the results of incubation study. 


\section{Acknowledgement}

Authors are grateful to the Alliance for Green Revolution in Africa (AGRA), for funding the study. We thank the department of Soil and Geological Sciences, SUA for their support during laboratory work.

Conflict of interest: The authors declare that they have no conflict of interest.

\section{REFERENCES}

1. Grant CA, Flaten DN, Tomasiewicz DJ, Sheppard SC. The importance of early season phosphorus nutrition. Canadian Journal of Plant Science. 2001; 81(2), 211-224.

2. Ross HM, Middleton A. Phosphorus fertilizer application in crop production. Agri-Facts, Alberta Agriculture and Rural Development Research and Innovation Division Agriculture Centre, Lethbridge. 2001. https://www.researchgate.net/profile/Dilip...of...phosphorus.../542-3.pdf site visited on 4 June 2018.

3. Marschner H. Marschner's mineral nutrition of higher plants. Academic press. 2011.

4. Sharpley AN, Daniel T, Wright B, Kleinman P, Sobecki T, Parry R, Joern B. National research project to identify sources of agricultural phosphorus loss. Better Crops. 1999; 83(4), 12-14

5. Usman K. Effect of phosphorus and irrigation levels on yield, water productivity, phosphorus use efficiency and income of lowland rice in northwest Pakistan. Rice Science. 1999; 20(1): 61-72.

6. Tian Z, Li J, He X, Jia X, Yang F, Wang Z. Grain Yield, Dry Weight and Phosphorus Accumulation and Translocation in Two Rice (Oryza sativa L.) Varieties as Affected by Salt-Alkali and Phosphorus. Sustainability. 2017; 9(8) 1461pp.

7. Alkurdi MI. Impact of Nitrogen and Phosphorus efficiency on the growth and flowering of Helichry sumbractum. Journal of Agriculture and Veterinary Science. 2014; 7(2): 7-12.

8. Sundaresh R, Basavaraja PK. Influence of Different Levels of Phosphorus and Potassium on Growth, Yield Attributes and Economics of Finger Millet in Low Phosphorus and Potassium Soils of Eastern Dry Zone of Karnataka, India. Int. J. Curr. Microbiol. App. Sci. 2017; 6(11), 3559-3566.

9. Huber DM, Graham RD. The role of nutrition in crop resistance and tolerance to diseases. Mineral nutrition of crops: fundamental mechanisms and implications. 1999; 169, 206.

10. Dordas C. Role of nutrients in controlling plant diseases in sustainable agriculture: a review. In Sustainable agriculture. 2009; 443-460 pp.

11. Abebe Z. On-farm Yield variability and Responses of Common bean (Phaseolus vulgaris L.) Varieties to Rhizobium Inoculation with Inorganic Fertilizer Rates. Journal of Animal and Plant Sciences. 2017; 32(2) 5120-5133.

12. Thomason W. Understanding Phosphorus Behavior in Soils. 2002. https://www.noble.org/news/.../2002/.../understanding-phosphorus-behavior-in-soils/. Accessed on 30 May 2018.

13. Myint AK, Yamakawa T, Kajihara Y, Zenmyo T. Application of different organic and mineral fertilizers on the growth, yield and nutrient accumulation of rice in a Japanese ordinary paddy field. Science World Journal. 2010; 5(2). $51 \mathrm{pp.}$

14. Bokossa HK, Saïdou A, Fiogbé ED, Kossou D. Decomposition rate of pigs' manures and nutrient release pattern in wetland condition. Agriculture, Forestry and Fisheries. 2014; 3(4): 271-278.

15. Zamil SS, Halim MA, Ashraf-Uz-Zaman K, Chowdhury MA. Available nitrogen and phosphorus release pattern from poultry manure, cow-dung and bio-gas slurry. International Journal of Business, Social and Scientific Research. 2015; 03:1136-142 pp.

16. Abdou G, Ewusi-Mensah N, Nouri M, Tetteh FM, Safo EY, Abaido, RC. Nutrient release patterns of compost and its implication on crop yield under Sahelian conditions of Niger. Nutrient cycling in agro ecosystems. 2016; 105(2) 117-128.

17. Kolawole GO. 2016. Nutrient release patterns of tithonia compost and poultry manure in three dominant soils in the southern guinea savanna, Nigeria. Int. J. Plant Soil Sci. 2016; 10(5): 1-8.

18. Okalebo JR, Gathua KW, Woomer PL. Laboratory methods of soil and plant analysis: a working manual second edition. Sacred Africa, Nairobi. 2002; 29-32pp. 
19. Moberg JD. Soil and Plant Material Analysis Manual. Royal Veterinary and Agricultural University, Copenhagen, Denmark.2001.

20. Jember TS. Management of Salt Affected Soils, Soil Analysis for Soil Salinity and Soil fertility status. Amazon Distribution GmbH, Leipzig. 2011. 43-69.

21. Food and Agriculture Organization (FAO). Guidelines for Soil Description. $4^{\text {th }}$ Edition Food and Agriculture Organization of the United Nation. Rome, Italy. 2006; $110 \mathrm{p}$

22. Warncke D, Brown JR. pH and Lime Requirement. Recommended chemical soil test procedures for the North Central Region. North Central Regional Research Publication No. 221, Missouri, Columbia. 1998; 13-14pp.

23. Nelson DW, Sommers LE. Total carbon, organic carbon, and organic matter. Methods of soil analysis part 3-chemical methods, (methods of soil analysis). 1996; 3: 961-1010.

24. Olsen SR, Cole CV, Watanabe FS, Dean LA. Estimation of available phosphorus in soils by extraction with sodium bicarbonate. USDA Circular No. 939, United States Department of Agriculture, Washington, DC., USA. 1954; pp. 1-18.

25. Kuo S, Phosphorus. Methods of soil analysis. Part 3. 1996; p. 869-919.

26. Landon JR. Booker tropical soil manual: a handbook for soil survey and agricultural land evaluation in the tropics and subtropics. 1991.

27. McCauley A, Jones C, Jacobsen J. Soil pH and organic matter. Nutrient management module, 8. 2009; 1-12.

28. Msanya BM, Kimaro DN, Kileo EP, Kimbi GG, Mwango SB. Land Suitability Evaluation for the Production of Crops and Extensive Grazing: A Case Study of Wami Plains in Morogoro Rural District, Tanzania. 2001; 71-73pp.

29. Kim KS, Yoo JS, Kim S, Lee HJ, Ahn KH, Kim I.S. Relationship between the electric conductivity and phosphorus concentration variations in an enhanced biological nutrient removal process. Water science and technology. 2007; 55(1-2): 203-208.

30. Kuhn NJ, Armstrong EK, Ling AC, Connolly KL, Heckrath G. Interrill erosion of carbon and phosphorus from conventionally and organically farmed Devon silt soils. Catena. 2012; 91 94-103.

31. Suñer L, Galantini JA. Texture influence on soil phosphorus content and distribution in semiarid Pampean grasslands. Int. J. Plant Sci. 2015; 7: 109-120.

32. Jones US, Katyal JC, Mamaril CP, Park CS. Wetland nutrients deficiencies other than nitrogen. In: Rice research strategies for the future. International Rice Research Institute. Los Banos, Philippines. 1982; pp 327378.

33. Andrew T. Characterization of Sukumawera and Kisarawe bat guano from Tanzania as soil amendment and source of plant nutrients. Dissertation for Award of MSc Degree at Sokoine University of Agriculture, Morogoro, Tanzania. 2016; 30-38pp.

34. Sikazwe O, de Waele B. Assessment of the quality and reserves of Bat Guano at Chipongwe and Kapongo caves near Lusaka as fertilizer materials. Journal of Science and technology (special edition). 2004; 32-42.

35. Zapata F. Agronomic evaluation of guano sources by means of isotope techniques In: Nuclear Techniques in Soil-Plant Studies for Sustainable Agriculture and Environmental Preservation. International Atomic Energy Agency, Vienna, Austria. 1995; 83-105.

36. Bird MI. A long record of environmental change from bat guano deposits in Makangit Cave, Palawan, Philippines. Earth Env. Sci. T. Roy. Soc. Edin. 2007; 98:59-69.

37. Cleary DM, Wynn JG, Ionita M, Forray FL, Onac BP. Evidence of long-term NAO influence on East-Central Europe winter precipitation from a guano-derived $\delta 15 \mathrm{~N}$ record. Scientific Reports. 2017. 7(1) 14095.

38. Hallimond AF. Pyroxenes, amphibole, and mica from the Tiree marble. Mineral. Mag. 1947; 28, 230-243.

39. Fageria NK, Baligar VC. Ameliorating soil acidity of tropical Oxisols by liming for sustainable crop production. Advances in agronomy. 2008; 99, 345-399.

40. Nafiu A. Effects of soil properties on the kinetics of desorption of phosphate from Alfisols by anion-exchange resins. J. Plant Nutr. Soil Sci. 2009; 172: 101-107.

41. Kaloi GM, Bhughio RN, Panhwar S, Junejo AH, Bhutto MA. Influence of incubation period on phosphate release in two soils of district Hyderabad. J. Anim. Plant Sci. 2011; 21: 665-670.

42. Akhtar M, Alam SM. Effect of incubation period on phosphate sorption from two P sources. J. Biol. Sci. 2001. 1: $124-125$ 
43. Bünemann EK, Oberson A, Liebisch F, Keller F, Annaheim KE, Huguenin-Elie O, Frossard E. Rapid microbial phosphorus immobilization dominates gross phosphorus fluxes in a grassland soil with low inorganic phosphorus availability. Soil Biology and Biochemistry. 2012; 51: 84-95.

44. Havlin JL, Tisdale S. L, Beaton JD, Nelson WL. Soil Fertility and Fertilizers: An Introduction to Nutrient Management. Vol. 515. Upper Saddle River, NJ: Pearson Prentice Hall. 2005; pp. 244-254.

45. Boukhalfa-Deraoui, N., Hanifi-Meklich, L., Mihoub, A. Effect of Incubation Period of Phosphorus Fertilizer on some Properties of Sandy Soil with Low Calcareous Content, Southern Algeria. Asian Journal of Agricultural Research. 2015; 9 (3): 123-131.

46. Hossain, I., Kashem, O., Sarkar, A. Correlations of available phosphorus and potassium with ph and organic matter content in the different forested soils of Chittagong Hill Tracts, Bagladesh. International journal of forests, soil and erosion. 2014; Vol. 4 No. 1: 7-10

47. Goundar, M. S., Morrison, R. J., Togamana, C. 2014. Phosphorus requirements of some selected soil types in the Fiji sugarcane belt. The South Pacific Journal of Natural and Applied Sciences. 2014; 32(1): 1-10.

48. Anderegg, J. C., and Naylor, D. V. Phosphorus and $\mathrm{pH}$ relationships in an andic soil with surface and incorporated organic amendments. Plant and soil. 1988; 107(2), 273-278. 